\title{
Bibliografía
}

\section{Archivos/Fuentes primarias}

Blackwell Family Papers, 1759-1960. Manuscript Division, Library of Congress, Washington, D.C. Julio 2016.

Blackwell Family Papers, 1831-1981. Schlesinger Library, Radcliffe Institute, Harvard University, Cambridge, Mass. Marzo de 2015.

Isaac Goldberg Papers, 1919-1938. Manuscripts and Archives Division, New York Public Library, NY. Mayo 2013.

Gabriela Mistral Papers. Manuscript Division, Library of Congress, Washington, D.C. 21 de julio 2016.

Tour Tendered by the Government of the United States to the International American Conference, October $3 d$ to November 13th, 1889: Under the Personally-Conducted Tourist System of the Pennsylvania Railroad Company (1890): Philadelphia: Allen, Pennsylvania Railroad Co.

Sesiones desde el 2 de octubre al 13 de diciembre de 1889: Relación del viaje de los señores delegados a diversos lugares de los Estados Unidos. Notas tomadas de "El Avisador Hispano-Americano" de Nueva York (1890): Nueva York: El Avisador Hispano-Americano.

\section{Fuentes secundarias}

“Ac·Cent.Tchu·Ate the Intertextuality: Interview! with Translator (Megan McDowell)" (2019): Cagibi. https://cagibilit.com/interview-with-translator-megan-mcdowell/. Último acceso: 9 de noviembre 2020.

Allen, Bruce y Kato, Daniela (2014): “Toward and Ecocritical Approach to Translation: A Framework". The 2014-2015 Report on the State of the Discipline of Comparative Literature. https://stateofthediscipline.acla.org/entry/toward-ecocriticalapproachtranslation-conceptual-framework. Último acceso, 16 de agosto 2020.

Allen, Esther, y Bernofsky, Susan (2013): In Translation: Translators on Their Work and What It Means. New York: Columbia University Press.

Allen, Esther (2013): “Footnotes sans Frontières: Translation and Textual Scholarship”. Perspectives on Literature and Translation. Eds. Brian Nelson and Brigid Maher. London; New York: Routledge, pp. 210-220.

Armitstead, Claire (2018): “Lost in (mis)translation? English take on Korean novel has critics up in arms”. The Guardian. www.theguardian.com/books/booksblog/2018/jan/15/lost-in -mistranslation-english-take-on-korean-novel-has-critics-up-in-arms. Último acceso: 7 de septiembre 2020.

Bassnett, Susan y Lefevere, André (1990). Translation, History, and Culture. London; New York: Pinter Publishers.

Bastian, Jean Pierre (2006). “Modelos de mujer protestante: ideología religiosa y educación femenina, 1880-1910”. Presencia y Transparencia: La Mujer en la historia de México. Ed. Carmen Ramos-Escandón. Ciudad de México: Colegio de México, pp.163-180. 
Benjamin, Walter (1988). "The Task of the Translator: An Introduction to the Translation of Baudelaire's Tableux Parisiens". Illuminations: [Essays and Reflections]. New York: Schocken Books.

Berger, Mark T. (1995): Under Northern Eyes: Latin American Studies and U.S. Hegemony in the Americas, 1898-1990. Bloomington: Indiana Univ. Press.

Blackwell, Alice Stone (1929): Some Spanish-American Poets. New York; London: D.Appleton. - (1935): “Poetry from Spanish America”, Woman's Missionary Friend, pp. 407-408.

Cabello Hutt, Claudia (2014): “Tejiendo un sueño americano: el poder de las redes de Gabriela Mistral con Estados Unidos en los años 1920 y 1930”. Eds. Carolina Alzate, y Darcie Doll. Redes, Alianzas y Afinidades: Mujeres y Escritura en América Latina: Homenaje a Montserrat Ordóñez (1941-2001). Santiago: Universidad de Chile, pp. 85-104.

Carson, Anne (2009): Eros the Bittersweet. Champaign: Dalkey Archive Press.

- (2012): "Transcript for Poesis with Anne Carson". Interview with To the Best of Our Knowledge, Poems Old and New, by Jim Fleming. NPR. http://archive.ttbook.org/book/ transcript/transcript-poesis-anne-carson. Último acceso: Febrero 2021.

- (2016): "Variations on the Right to Remain Silent”. Float. New York: Alfred K. Knopf.

Carson, Anne/ Stone, Bianca/ Currie, Robert and Sophocles (2012): Antigonick: Sophokles. Toronto: McClelland \& Stewart.

Castro-Klarén, Sara (2003): “Framing Pan-Americanism: Simón Bolívar's Findings." CR: The New Centennial Review, vol. 3, no. 1, pp. 25-53. www.jstor.org/stable/41949370. Último acceso: Septiembre 2018.

Chau, Bonnie (2020): "594 ways of reading Jane Eyre”. Poets and Writers. https://www.pw. org/content/594_ways_of_reading_jane_eyre. Último acceso: 4 de mayo 2020.

Cheetham, D. (2016): “Literary translation and conceptual metaphors: From movement to performance". Translation Studies, 9 (3), pp. 241-255. https://doi.org/10.1080/ 14781700.2016.1180543. Último acceso: 7 de julio 2020.

Code, Grant H. (1920): “South-American Poetry.” Poetry, vol. 16, no. 5, 1920, pp. 280-283. JSTOR, www.jstor.org/stable/20572749. Último acceso: 16 Febrero 2016.

Coester, Alfred (1916): The Literary History of Spanish America. Macmillan Co.: New York.

- (1927). "Practical Pan Americanism". Hispania, 10 [2], pp. 95-98. doi:10.2307/330959. Último acceso: Marzo 2016.

Cohen, Jonathan (2015): "Remembering Salvador de la Selva -Pioneer Leader of Pan American Poetry”. Literature and Arts of the Americas. Issue 91. Vol. 48 No.2, pp. 193-199.

Cohn, Deborah N. (2006): “A Tale of Two Translation Programs: Politics, the Market, and Rockefeller Funding for Latin American Literature in the United States during the 1960s and 1970s". Latin American Research Review 41.2, pp. 139-64.

Colectivo Frank Ocean (2021): "Poemas contra la policía”. Disponible en: https://tripwirejour nal.files.wordpress.com/2021/01/colectivo_tw17.pdf Último acceso: Mayo 2021.

Cronin, Michael (2006): Translation and Identity. London; New York: Routledge.

Degiovanni, Fernando (2015): “Una disciplina de guerra: Pedro Henríquez Ureña y el latinoamericanismo". Revista de Crítica Literaria Latinoamericana. N.82, pp. 136-160.

- (2016): "Opacidad, disciplina, latinoamericanismo". Políticas y estrategias de la crítica: ideología, historia y actores de los estudios literarios. Eds. Sergio Ugalde Quintana y Ottmar Ette. Madrid: Iberoamericana Vuervuert, pp. 205-223.

Delpar, Helen (2008): Looking South: The evolution of Latin Americanist scholarship in the United States, 1850-1975. Tuscaloosa: University of Alabama Press. 
Doyle, Henry Grattan (1925): “Spanish Studies in the United States". Bulletin of the Pan American Union, Volume 60, Issue 1, 223-234.

Duong, Paloma (2014): “Amateur Citizens: Culture and Democracy in Contemporary Cuba”. Diss. Columbia University.

Eipper, John E. (2000): “The Canonizer De-Canonized: the Case of William H. Prescott”. Hispania. 83.3, pp. 416-427.

Elliott, L. E. (1917): “Some Poets of Chile.” Pan-American Magazine 26.2, pp. 64-71.

Espinosa, J. Manuel (1977): Inter-American Beginnings of U.S. Cultural Diplomacy, 19361948. Washington: Bureau of Educational and Cultural Affairs, U.S. Dept. of State: For sale by the Supt. of Docs., U.S. Govt. Print. Off.

"Ezra Pound" (s.f.): Poetry Magazine. www.poetryfoundation.org/poets/ezra-pound. Último acceso: 23 de mayo 2021.

Fan, Jiayang (2018): “Hank Kang and the Complexity of Translation”. The New Yorker www.new yorker.com/magazine/2018/01/15/han-kang-and-the-complexity-of-translation. Último acceso: 7 de septiembre 2020.

Feinsod, Harris (2017): The Poetry of the Americas: From Good Neighbors to Countercultures. New York: Oxford University Press.

Findlay, Jean (2015): Chasing Lost Time: The life of C. K. Scott Moncrieff. New York: Farrar, Straus \& Giroux.

Fisher, Chas. E. (1947): “A Much Travelled Engine Pennsylvania R. R. No. 1053”. The Railway and Locomotive Historical Society Bulletin, no. 70, 1947, pp. 76-79. www.jstor.org/stable/ 43519931. Último acceso: Mayo 2021.

Ford, J. D. M. (1919): Main Currents of Spanish Literature. New York: H. Holt and Company.

Fox, Claire F. (2013): Making Art Pan American: Cultural Policy and the Cold War. Minneapolis, MN: University of Minnesota Press.

Friedman, Max P. (2012): Rethinking Anti-Americanism: The History of an Exceptional Concept in American Foreign Relations. Cambridge: Cambridge University Press.

Garber, Marjorie (2009). Academic Instincts. Princeton University Press, 2009. ProQuest Ebook Central, https://ebookcentral-proquest-com.pva.uib.no/lib/bergen-ebooks/detail.action? doclD=617327. Último acceso: Febrero 2021.

Garcia, Frederick C. H. (1972): “Critic Turned Author: Isaac Goldberg.” Luso-Brazilian Review, vol. 9, no. 1, 1972, pp. 21-27. JSTOR, www.jstor.org/stable/3512836. Último acceso: Octubre 2018.

Gentzler, Edwin (2007): Translation and Identity in the Americas: New Directions in Translation Theory. New York: Routledge.

Gobat, Michel (2013): “The Invention of Latin America: A Transnational History of Anti Imperialism, Democracy, and Race". The American Historical Review 118.5, pp. 1345-75.

Goldberg, Isaac y Ford, J D. M. (1920). Studies in Spanish-American Literature. New York: Brentano's.

- (1929): “A Boston Boyhood". The American Mercury, pp. 354-361.

- (1924): “As Latin America sees us”. The American Mercury, pp. 465-471.

- (1933): "Notes from a Multilingual Career”. Books Abroad. Vol. 7, No 3. pp. 271-273.

Goyal, Sana (2019): “In other words: four translators reflect on women on translation".

Wasafiri Magazine. https://www.wasafiri.org/article/four-translators-reflect-onwomen-intranslation/. Último acceso: 6 de agosto, 2020.

Göransson, Johannes (2018): Transgressive Circulation: Essays on Translation. Blacksburg, Virginia: Noemi Press. 
Hofmann, Michael (2017): “An interview with Michael Hofmann." Asymptote Journal. www. asymptotejournal.com/interview/an-interview-with-michael-hofmann/. Último acceso: Julio 2017.

Horsman, Reginald (1981): Race and manifest destiny: The origins of American racial Anglo Saxonism. Cambridge: Harvard University Press.

Hughes, Robert (2014): "Bernard Stiegler Philosophical Amateur, or, Individuation from Eros to Philia”. Diacritics, vol. 42, no. 1, 2014, pp. 46-67. JSTOR, www.jstor.org/stable/ 43304270. Último acceso: Julio 2020.

Iber, Patrick (2015): Neither Peace nor Freedom: The Cultural Cold War in Latin America. Cambridge: Harvard University Press.

John Hopkins University (s. f.): “The Writing Seminars”. https://writingseminars.jhu.edu/ events/turnbull-lectures/. Último acceso 23 de mayo 2021.

Kagan, Richard L. (1996): "Prescott's Paradigm: American Historical Scholarship and the Decline of Spain." The American Historical Review, vol. 101, no. 2, pp. 423-446. JSTOR, www.jstor.org/stable/2170397. Último acceso: Julio 2017.

Klingenstein, Susanne (1998): Jews in the American Academy, 1900-1940: The Dynamics of Intellectual Assimilation. Syracuse, NY: Syracuse University Press.

Kristal, Efraín (2013): “Borges y la traducción”. Lexis. v.23. n 1. p-3-23.

Lau Jaiven, Ana y Rodríguez, Roxana (2014): "Panamericanismo femenino y protestantismo en México a través de la vida de la profesora Adelia Palacios Mendoza”. Revista Historia Autónoma, n. - 4, pp. 145-56. https://revistas.uam.es/historiaautonoma/article/view/ 479. Último acceso: Mayo 2021.

Lee, Muna (1924): “Contemporary Spanish-American Poetry." The North American Review, vol. 219, no. 822, pp. 687-698., www.jstor.org/stable/25113307.

- (2004). Ed. Jonathan Cohen. A Pan-American Life: Selected Poetry and Prose of Muna Lee. Madison: University of Wisconsin Press.

Lefevere, André (1990): Translation, History, Culture. London: Routledge.

- (1992): Translation, History, Culture: A Sourcebook. London: Routledge.

Lispector, Clarice (1977): “Última entrevista”. TV Cultura, por Julio Lerner.

Livingston, Victoria (2015): "Translating Latin America: Harriet de Onís and the U.S. publishing market”. Diss. Boston University.

McNamara, Nathan Scott (2017): "The Making of a Tireless Literary Translator (Why Megan MacDowell Never Stops Working”. Literary Hub. https://lithub.com/the-making-of-atireless-literary-translator/. Último acceso: Abril 2021.

Majumdar, Saikat (2017): “The Critic as Amateur”. New Literary History, vol. 48 no. 1, pp. 1-25. Project MUSE, doi:10.1353/nlh.2017.0000. Último acceso: Abril 2021.

Mandujano, Graciela (1916). "Los idiomas extrangeros [sic] en la enseñanza secundaria de Chile". Proceedings of the Second Pan American Scientific Congress. Section IV: Education. Washington: Govt. Print, pp. 574-576.

Martí, José (1991): “Congreso Internacional de Washington”. Obras Completas. Volumen 6. La Habana: Editorial Ciencias Sociales de la Habana.

Mistral, Gabriela (2002): “Una amiga de los poetas suramericanos: Alice Blackwell Stone”. Ed. Otto Morales Benitez. Gabriela Mistral: Su prosa y poesía en Colombia. Santa Fe de Bogotá: Convenio Andrés Bello.

- (1957): Selected Poems of Gabriela Mistral (translated by Langston Hughes). Indiana University Press. 
Molloy, Sylvia (2005): "Latin America in the US Imaginary: Postcolonialism, Translation, and the Magic Realism Imperative". Ideologies of Hispanism. Ed. Mabel Moraña. Nashville: Vanderbilt UP, pp. 189-200.

- (1998): "Lost in translation: Borges, the Western Tradition and Fictions of Latin America". Ed. Evelyn Fishburn. Borges and Europe Revisited. London: Institute of Latin American Studies.

- (1988): "Sarmiento, lector de sî mismo en Recuerdos de provincia". Revista Iberoamericana. Vol. LIV, N. 143. https://doi.org/10.5195/reviberoamer.1988.4465 Último acceso: Abril 2021.

- (2017): "Translation as a Deviant Practice”. Charla en la Universidad de Richmond, Virginia. 4 de febrero de 2017.

Monroe, Harriet (1925): “Pan-American Concord." Poetry, vol. 26, no. 3, pp. 155-158. www. jstor.org/stable/20575103. Último acceso: Mayo 2021.

Muna Lee (ed.) (1925): Spanish-American Number. Poetry, vol. 26, no. 3 JSTOR, https://www. jstor.org/stable/20575066. Último acceso: Mayo 2021.

Munday, Jeremy (2008): Style and Ideology in Translation: Latin American Writing in English. New York: Routledge.

Myers, Jacob W. (1922): "The Beginning of the German Immigration in the Middle West". Journal of the Illinois State Historical Society (1908-1984). 15, pp. 592-599.

Nester, William (2013): “The Monroe Doctrine." The Age of Jackson and the Art of American Power, 1815-1848, University of Nebraska Press, pp. 83-87. JSTOR, www.jstor.org/stable/ j.ctt1ddr80h.10. Último accceso: Marzo 2017.

0’ Rourke, Meghan (2010): “The Unfolding” The New Yorker. https://www.newyorker.com/ma gazine/2010/07/12/the-unfolding Último acceso, 4 de noviembre, 2020.

Oxford English Dictionary (2002): Oxford, England: Oxford University Press.

Pane, Remigio U. (1943): “Two Hundred Latin American Books in English Translation: A Bibliography”. The Modern Language Journal, vol. 27, no. 8, pp. 593-604. www.jstor.org/ stable/316423. Último acceso: Febrero 2017.

Pound, Ezra (2009): “A Retrospect” and “A few Dont's”. Poetry Magazine. https://www.poetry foundation.org/articles/69409/a-retrospect-and-a-few-donts Último acceso, 10 de abril, 2021.

Pita González, Alexandra y Grillo, María del Carmen (2012): "Historia e imperialismo: Yanquilandia bárbara de Alberto Ghiraldo (1929)”. Pensar El Antiimperialismo: Ensayos De Historia Intelectual Latinoamericana, 1900-1930. México, D.F: El Colegio de México.

Prismatic Jane Eyre, An Experiment in the Studies of Translations. Oxford Comparative Criticism and Translation. https://prismaticjaneeyre.org/ Último acceso: Abril 2021.

Rabassa, G. (2005). If This Be Treason: Translation and its Dyscontents: a Memoir. New York, NY: New Directions Book.

Reid, John T. (1977): Spanish American Images of the United States: 1790-1960. Gainesville: The University Presses of Florida.

- (1942): “Alfred Coester." Hispania, vol. 25, no. 3, pp. 263-271. JSTOR, www.jstor.org/ stable/334214. Último acceso: Diciembre 2016.

Rippy, J. Fred (1922): "Literary Yankeephobia in Hispanic America”. The Journal of International Relations, vol. 12, no. 3, pp. 350-371. JSTOR, www.jstor.org/stable/29738498. Último acceso: Diciembre 2016.

Salvatore, Ricardo (2016): Disciplinary Conquest: U.S. Scholars in South America, 19001945. Durham: Duke University Press. 
- (2005): "Library Accumulation and the Emergence of Latin American Studies". Comparative American Studies 3, No 4, pp. 415-436.

Sarmiento, Domingo F. (1850): Recuerdos De Provincia. Santiago: Imprenta de Julio Belin i Compañía.

Sarmiento, Domingo F. y Ross, Kathleen (2004): Facundo: Civilization and Barbarism. Berkeley, Calif: University of California Press.

Sheinin, David (2000): Beyond the Ideal: Pan Americanism in Inter-American Affairs. Westport, Conn.: Greenwood Press.

Simon, Sherry (1996): Gender in Translation. Cultural Identity and the Politics of Transmission. London: Routledge.

- (2013): Cities in Translation: Intersections of Language and Memory. New York: Taylor and Francis.

Siskind, Mariano (2014): Cosmopolitan Desires: Global Modernity and World Literature in Latin America. Evanston, Illinois: Northwestern University Press.

Smith, Joseph (2000): "The First Conference of American States (1889-1890) and the Early Pan American Policy of the United States". Ed. David Sheinin Beyond the Ideal: Pan Americanism in Inter-American Affairs. Westport, Conn.: Greenwood Press.

Smith, Deborah (2017): “Why Readers Are Embracing Translation?”. Financial Times. https:// www.ft.com/content/642f68f0-2a7d-11e7-bc4b-5528796fe35c. Último acceso: Septiembre 2017.

Staff, Harriet (2012): "Two Reviews of Anne Carson XE "Carson, Anne" 's Antigonick, Pro and Con”. Poetry Magazine. www.poetryfoundation.org/harriet-books/2012/08/two-reviewsof-annecarsons-antigonick-pro-and-con. Último acceso: Abril 2021.

Stebbins, Robert A. (1977): "The Amateur: Two Sociological Definitions". The Pacific Sociological Review, vol. 20, no. 4, pp. 582-606. JSTOR, www.jstor.org/stable/1388717. Último acceso: Abril 2021.

Stiegler, Bernard (s. f.): “Amateur”. Ars Industrialis (Association internationale pour une politique industrielle des technologies de l'esprit). Translated by Robert Hughes. http:// arsindustrialis.org/amateur-english-version. Último acceso: Mayo 2021.

- (2017): “The Quarell of the Amateurs”. Boundary 2, 44 (1), pp. 35-52. https://doi.org/10. 1215/01903659-3725857. Último acceso: Abril 2021.

Subercaseaux, Bernardo (2010): Literatura y prensa de la independencia, independencia de la literatura. Revista Chilena de Literatura. (77). https://revistas.uchile.cl/index.php/RCL/ar ticle/view/9034/45226 Último acceso: Mayo 2021.

Swiggett, Glen L. y Claxton, Philander P. (1917): Proceedings of the Second Pan American Scientific Congress: Washington, Monday, December 27, 1915 to Saturday, January 8, 1916. Washington: Government Printing Office.

"The Mission of Poetry in Pan American Relations" (1918): Ed. Albert Shaw. The American Review of Reviews, an International Magazine, LVII, pp. 319-320.

Torruella, Juan R. (2007). Global intrigues: The era of the Spanish-American War and the rise of the United States to world power. San Juan, P.R: La Editorial, Universidad de Puerto Rico.

Tymoczko, Maria y Gentzler, Edwin (2002): Translation and Power. Amherst: University of Massachusetts Press.

Tymoczko, Maria (2010): Translation, Resistance, Activism. Amherst: University of Massachusetts Press.

Valencia, Alba (1993): “El legado de tres maestros, Lenz, Oroz y Rosales”. Archivo de Referencias Críticas. Disponible en Biblioteca Nacional Digital de Chile http://www.biblio 
tecanacionaldigital.gob.cl/bnd/628/w3-article-203668.html. Último acceso: Septiembre 2017.

Venuti, Lawrence (2008): The Translator's Invisibility: A History of Translation. London; New York: Routledge.

- (2019): Contra Instrumentalism, A Translation Polemic. Lincoln: University of Nebraska Press.

Walsh, Rodolfo y Piglia, Ricardo (2013): “Nota al pie”. Cuentos completos. Buenos Aires: De la Flor.

Williams R. John (2009): “Modernist Scandals: Ezra Pound Translations of "the" Chinese Poem”. Ed. Sabine Sielke. Orient and Orientalisms in Us-American Poetry and Poetics. New York: Peter Lang.

Willson, Patricia (2004): La constelación del sur: traductores y traducciones en la literatura argentina del siglo XX. Buenos Aires: Siglo Veintiuno Editores Argentina.

- (2001): “La fundación vanguardista de la traducción”. Borges Studies Online. https://www. borges.pitt.edu/bsol/pw.php Último acceso: Agosto 2017.

Wittke, Carl F. (1949): "Immigration Policy Prior to World War I". The Annals of the American Academy of Political and Social Science, vol. 262, pp. 5-14. JSTOR, www.jstor.org/stable/ 1026968. Último acceso: Mayo 2021.

Zerker, Sally F. (1982): The Rise and Fall of the Toronto Typographical Union, University of Toronto Press. JSTOR, www.jstor.org/stable/10.3138/j.ctt15jvw33.11. Último acceso: Mayo 2021. 
